\title{
Spominska retorika v literarni esejistiki Josepha Rotha
}

\author{
Matjaž Birk
}

Filozofska fakulteta Univerze v Mariboru, Oddelek za germanistiko, Koroška cesta 16, 2000 Maribor, Slovenija

https://orcid.org/0000-0001-8905-9823

matjaz.birk@um.si

Razprava z izhodišč teorije spominske retorike (A. Erll) osvetljuje pripovedne strategije in korelacijo med narativizacijo kolektivnega spomina in literarno reprezentacijo identitet in kulturnih praks vzhodnoevropskega judovstva $v$ Juden auf Wanderschaft (Judje na popotovanju), osrednjem literarnoesejističnem deluz judovsko tematiko avstrijsko-judovskega pisatelja Josepha Rotha (1894-1939). Avtor s povezovanjem izkustvenega in antagonističnega spominskoretoričnega načina, ki nastopata $v$ funkcionalnem sozvočju z monumentalnim, legitimira kulturne prakse vzhodnoevropskega judovstva, umeščene med duhovnim in čutnim. S kritično dekonstrukcijo zahodnoevropskih ideoloških diskurzov istočasno razkriva judovskokulturne samoprevare in v prepletu antagonističnega z refleksivnim načinom senzibilizira bralca za dojemanje »drugega stanja in konstrukcijskega značaja kulture. Premik spominskoretoričnega težišča s kontrastnega na korespondenčnega modelira človečnost $v$ nadetnični razsežnosti in jo izpostavi kot idejni postulat za odnos do vzhodnega judovstva kot komplementarne tujosti ( 0 . Schäffter). Kljub kulturnim binarnostim kot produktu antagonistične spominske retorike in historičnemu pesimizmu o usodi Judov, ponujajo hibridne identitetne konstrukcije bralcu prepričljive signale za razkrivanje transdiferenc in možnosti idejnega večglasja v medkulturni komunikaciji.

Ključne besede: avstrijska književnost / Roth, Joseph: Juden auf Wanderschaft / literarna esejistika / Vzhodna Evropa / judovstvo / kolektivni spomin / kolektivna identiteta / idejna in kulturna polifonija

\section{Družbeni in kulturni konteksti in teksti}

Joseph Roth (1894-1939), avstrijski pisatelj judovskega rodu, se je rodil na skrajnem vzhodu Habsburške monarhije, v obmejnem mestu Brody, kjer so Judje predstavljali večinski delež prebivalstva. ${ }^{1}$ Brody je

\footnotetext{
${ }^{1}$ Prispevek je nastal v okviru programske skupine P6-0265, ki jo financira Javna agencija za raziskovalno dejavnost Republike Slovenije.
} 
bil pomembno središče judovskega verskega šolstva in prav tako razsvetljenstva oz. haskale (gl. Bos). ${ }^{2}$ Pisateljev odnos do judovskega porekla je bil skrajno ambivalenten (gl. Birk). V nekem pismu Stefanu Zweigu iz leta 1935 je Roth svoje judovstvo označil za "naključno lastnost [...] nekako tako kot moji svetli brki« (Roth, Briefe 417). ${ }^{3}$ Pripisoval mu je univerzalne razsežnosti - »Prej prihajamo iz 'emancipacije', iz človečnosti in 'človeškega' nasploh kot pa iz Egipta." (257) - in ga v evrocentričnem diskurzu poskušal pomiriti s katolištvom - „Dejansko ne vidim nobene druge poti kot Kalvarijo, ki vodi h Kristusu in nobenega večjega Juda." (423) -, da bi ga lahko afirmiral kot eno osrednjih evropskih referenčnih kultur, od katere se je vedno znova tudi samoironično ogradil: "Z užitkom sem odpadnik od Nemcev in Judov in sem na to ponosen." (421)

Protislovja $\mathrm{v}$ odnosu do judovstva kot konfesionalne in kulturne kategorije so značilna tudi za avtorjev literarni diskurz. Kot primer navedimo Rothov najpomembnejši roman z judovsko tematiko, leta 1930 objavljeni Hiob (Job), v katerem kot osrednji protagonist nastopa Mendel Singer. Njegovo življenje je posvečeno Bogu in razlagi Tore, vse dokler mu usoda $\mathrm{v}$ rutenski domovini in zatem $\mathrm{v}$ ameriški emigraciji ne nameni mesta sodobnega Joba. Iz usmiljenja vredne priče zastrašujoče božje moči in $\mathrm{v}$ nebo vpijočega protestnika zoper njo se življenjski brodolomec na koncu spremeni v posameznika, globoko zasidranega v božjem usmiljenju in božjega izbranca v svoji skupnosti. Avtor z njim deli izkušnjo zastrašujoče ambivalentnosti numinoznega, ki izziva jezo in prav tako nemir, strah in zlo.

Tudi druge Rothove judovske like zaznamuje ambivalenten in travmatičen odnos do pripadnosti skupnosti, še posebej če gre za vzhodno judovstvo. Tega je Roth postavil v središče svojega osrednjega esejističnega dela iz leta $1927 \mathrm{z}$ naslovom Juden auf Wanderschaft (Judje na popotovanju). Cilj pričujoče obravnave je s spominskoretorično naratološko analizo pripovednih strategij ugotoviti retorične načine kolektivnega spomina in osvetliti korelacijo med njegovo narativizacijo ter literarno reprezentacijo identitet in kulturnih praks vzhodnoevropskega judov-

${ }^{2}$ Poleg Judov, ki so v letih pisateljevega otroštva predstavljali več kot $70 \%$ prebivalstva, so v mestu Brody živeli tudi Poljaki, Ruteni, Nemci in nekateri drugi (gl. Kuzmany), ki so za poimenovanje mesta uporabljali skupen endonim (Krevs Birk 2019: 168), kar je ena od simptomatik za večjezikovno hibridnost prebivalstva, ki ji je s svojimi jeziki pripadal Roth. Ta se je v mitomanskih avtobiografskih konstrukcijah zaklinjal, da njegov rojstni kraj ni Brody, marveč bližnji Szwaby oz. Schwabendorf. $S$ tem se je hotel otresti negativne vzhodnojudovske stigme, kar mu je, če gre soditi po osmrtnici, nenazadnje celo do neke mere tudi uspelo (prim. Birk).

${ }^{3}$ Vse navedke iz Rothove korespondence in iz Juden auf Wanderschaft je prevedel avtor prispevka. 
stva, zasidranih v presečišču med kulturno identiteto in alteriteto. Že na podlagi namere, ki jo pripovedovalec izrazi v prvem eseju $-» V$ nadaljevanju bom poskusil opisati, kako on [vzhodnojudovski bratranec; M. B.] in njemu podobni živijo v domovini in v tujini.« (Roth, Juden 21) -, je namreč moč domnevati, da prav perspektiviranje pripovedovanega med lastnim in drugim oz. tujim kulturnim redom predstavlja eno osrednjih estetskih značilnosti obravnavane zbirke esejev.

Eseji kot "hibridna zvrst, ki singularnost literarne proze križa s pojmovno govorico mišljenja« (Juvan 107), temeljijo na avtorjevem izčrpnem poznavanju preteklosti in sedanjosti vzhodnoevropskega judovstva in njegove diaspore ter na avtorjevem osebnem izkustvu. Prav osebno izkustvo je tisto, ki odločilno zaznamuje Rothovo esejistiko, na kar je avtor spomladi leta 1927 v pismu Bennu Reifenbergu, uredniku feljtona pri Frankfurter Zeitung, opozoril tudi sam:

Počasen sem, temeljit, poln strahu, da bi kaj napak videl, moj »slog« vendarle ni nič drugega kot natančno poznavanje stanja - brez tega pišem slabo - kot Sieburg v Osterblattu. Ne pišem v prazno. Nobenih "misli« nimam - zgolj védenje. Denar moram imeti in šele v juniju bom gotov z Balkanom. V štirih tednih ne vem ničesar. Štirje tedni zadoščajo za reportažo ali za uvodnik. [...] Ta založba izdaja sodobno zgodovino, ne časopisa [...]. (Roth, Briefe 102-103)

Zaradi visoke stopnje heteroreferenčnosti esejev in poudarjene navezave na resnični svet, ki je produkt na znanju in izkustvu utemeljenega védenja ter pride do izraza $\mathrm{v}$ reprezentiranju sodobnosti in zgodovine vzhodnoevropskega judovstva, je za pripovedno konstruiranje identitet pri Rothu ključnega pomena insceniranje procesa kolektivnega spominjanja in spomina. Literatura postane njun medij, kadar določene izrazne oblike bralca pripravijo do tega, da literarno besedilo bere skladno s kognitivnimi shemami, ki so značilne za procese kolektivnega spominjanja. Aktualiziranje literarnega besedila kot spominskega medija je v tem primeru odvisno od strategije, ki jo imenujemo retorika kolektivnega spomina.

Retorika kolektivnega spomina je izrazito kontekstualistični (gl. Erll, tudi Koron) naratološki pristop. Gre za skupek besedilnih upodobitvenih postopkov, ki jih proizvajajo različna literarna izrazna sredstva. Retorika kolektivnega spomina se kaže $\mathrm{v}$ petih različnih načinih - $\mathrm{v}$ izkustvenem, monumentalnem, historizirajočem, antagonističnem in refleksivnem. $\mathrm{V}$ prvem, izkustvenem, je literarna reprezentacija predmet vsakdanjega komunikativnega spomina. $\mathrm{V}$ monumentalnem retoričnem načinu je pripoved del nadrejenega in zavezujočega kulturnega (etničnega, nacionalnega, verskega, spolnega itd.) obzorja človeškega razmišljanja in rav- 
nanja. To sta dva spominska načina, ki vsebujeta literarni register preteklosti. V historizirajoči obliki spominske retorike je literarna fikcija del zaključene preteklosti in predmet zgodovinopisja. Antagonistična oblika služi konfrontaciji konkurenčnih spominov nacionalnih, spolnih, socialnih, generacijskih, verskih in drugih skupnosti, medtem ko t. i. refleksivni način inscenira načine funkcioniranja in problematiko spominjanja ter omogoča kritično distanco do lastne spominske kulture. Prvi štirje načini spominske retorike imajo vlogo oblikovanja spomina in spominjanja, zadnji služi razmisleku o spominu kot medialnem konstruktu in njegovi družbeni pogojenosti. Analiza načinov spominske retorike se bo v nadaljevanju osredinila na literarna izrazna sredstva, slog in žanr, selekcijsko strukturo, intertekstualne, intermedialne in interdiskurzivne značilnosti ter na posebnosti pripovedovalčevega posredovanja in literarno konfiguracijo likov in prostorov.

\section{Juden auf Wanderschaft: nastanek, recepcija in načrti za poznejše izdaje dela}

Roth se je pisanja Juden auf Wanderschaft lotil spomladi leta 1926, ko je kot posebni dopisnik dnevnika Frankfurter Zeitung, svoje matične časopisne hiše, bival v Parizu. ${ }^{4}$ Zadnji esej je nastal zgodaj jeseni istega leta, ko je pisatelj kot poročevalec potoval po Sovjetski zvezi. Posamezne eseje je Roth pred knjižno izdajo objavil v časopisih Frankfurter Zeitung in Wiener Morgen. V knjižni obliki so izšli spomladi leta 1927 v zbirki Berichte aus der Wirklichkeit (Poročila iz resničnosti) pri berlinski Die Schmiede, ki je veljala za butično založbo nemške literarne avantgarde. ${ }^{5}$ Juden auf Wanderschaft so v nemškem judovskem časopisju doživeli navdušen sprejem; vodilni sionistični tednik, Jüdische Rundschau, jih je ocenil kot avtorjevo priznanje pripadnosti vzhodnemu judovstvu, $v$ katerem se zrcalita vzhodnojudovsko mišljenje in čutenje (gl. Gelber).

${ }^{4}$ V Parizu je Roth bival na Place de l'Odéon v Latinski četrti. Eseji iz zbirke so nastajali v hotelu in v različnih kavarnah, po Rothovi korespondenci sodeč (gl. Roth/ Zweig) tudi v znameniti Café de la Régence v prvem pariškem okrožju. V pismih je Roth izražal navdušenje nad svobodo in iskrivostjo duha, kultiviranostjo in odprtostjo prebivalcev »metropole sveta«, kot je v zanosu poimenoval francosko prestolnico. V času njegovega prvega bivanja v Parizu leta 1925 sta nastali potopisni zbirki Im mittäglichen Frankreich (Vopoldanski Franciji) in Die weißen Städte (Bela mesta). V njih avtor opisuje preplet kultur v mestih v dolini Rone in v Provansi ter ga kodira v univerzalnosti humanizma in krščanstva (gl. Baric).

${ }^{5} \mathrm{~V}$ berlinski Die Schmiede so poleg Rothovih zgodnjih romanov izšli tudi Kafkova Proces in Gladovalec ter zgodnja dela A. Döblina (gl.von Sternburg). 
$\mathrm{Ne}$ glede na ugodne kritike je bil avtor prepričan, da bi bil uspeh pri bralstvu še večji, če bi delo izšlo pri založbi z obsežnejšim programom in širšim krogom bralstva. ${ }^{6}$ Neposredno po zaključku redakcije Juden auf Wanderschaft je Roth načrtoval njihovo nadaljevanje, ki naj bi izšlo pod naslovom Die Juden und Antisemiten (Judje in antisemiti) sočasno pri založbi Gustav Kiepenheuer v Weimarju - ta je spomladi leta 1929 postala njegova matična založba - in pri amsterdamskem založniku Allert de Lange. Spomladi 1937 je Roth z dunajskim Richard Löwit Verlag sklenil pogodbo za posodobljeno izdajo dela. Načrti so se izjalovili, prva dva iz nepojasnjenih razlogov, zadnji spričo anšlusa.

Ob svojem prvem izidu leta 1927 je zbirka vsebovala predgovor in pet esejev. V predgovoru Roth ciljno publiko opredeli kot bralce, "pred katerimi vzhodnih Judov ni potrebno braniti; bralce, ki spoštujejo bolečino, človeško veličino in umazanijo, ki povsod spremlja trpljenje« in kot zahodne Evropejce, »ki se ne ponašajo s svojimi snažnimi žimnicami» (Roth, Juden 9). Prvi esej z naslovom »Ostjuden im Westen " (»zhodni Judje na Zahodu«) je programske narave in vsebuje komparativna razmišljanja o identiteti in družbenem položaju vzhodnoevropskega judovstva v izvornih deželah evropskega Vzhoda in diaspori. Sledijo eseji o življenju Judov v vzhodnoevropskem "shtetlu«, v Sovjetski zvezi in v vzhodnojudovskih skupnostih na Dunaju, v Berlinu, Parizu ter severnoameriških mestih, predvsem New Yorku. Za neuresničeno izdajo zbirke leta 1937 je avtor napisal nov obsežen predgovor in zaključek, ki sta bila vključena $\mathrm{v}$ poznejše izdaje dela. $\mathrm{V}$ zaključku avtor opozori na diskrepanco med historičnim in sočasnim diskurziviranjem družbenega položaja Judov v Sovjetski zvezi. Predgovor pa vsebuje aktualizacijo družbenega položaja nemških Judov po prihodu nacizma na oblast v Nemčiji in v migracijskih deželah. $\mathrm{V}$ predgovoru avtor prevzame odgovornost za vsebino svojega literarnega dela, ${ }^{7}$ kar je, kot bomo videli v nadaljevanju, značilno za pripovedovalčevo identiteto in njegov način posredovanja.

${ }^{6} \mathrm{~V}$ mislih je imel prestižno založbo S. Fischer-Verlag v Berlinu. Prizadevanja, da bi presedlal k njej, so dosegla vrhunec konec leta 1928, a željenih rezultatov vendarle niso prinesla.

${ }^{7}$ Po Genettovi tipologiji sodi Rothov predgovor iz leta 1937, ki je bil predviden za načrtovan, a nerealiziran ponatis dela, prevladujoče v kategorijo prevzemalnega avtentično avktorialnega tipa predgovora. Ker avtor v njem izrecno prevzame odgovornost za literarno delo, je predgovor prevzemalni (»préface assomptive«), avtentičen je, ker ga potrjujejo tudi drugi paratekstualni indici (npr. besedila oz. kritike na platnicah), in avktorialen, ker je domnevni avtor predgovora tudi resnični avtor esejev. Na podlagi posameznih mest $\mathrm{v}$ besedilu, ki kažejo na istovetnost med avtorjem predgovora in prvoosebnim pripovedovalcem $\mathrm{v}$ esejistični naraciji, bi predgovor lahko uvrstili tudi v skupino fiktivno aktorialnih predgovorov ("préface actoriale fictive«) (gl. Genette). 


\section{Spominska retorika in reprezentacija družbenih praks ter kolektivnih identitet vzhodnoevropskega judovstva}

Obravnavani eseji so epizodično strukturirane avtodiegetske pripovedi in kot take sodijo $\mathrm{v}$ skupino nizko mimetičnih načinov oz. malih pripovedi, ki jih bralec zaznava kot izraz vsakdanjega življenja in s tem komunikativnega spomina. Vendarle pa je $\mathrm{v}$ besedilih tudi več pripovednih odlomkov, ki jasno inscenirajo kulturni spomin. Ta se v komprimirani obliki najočitneje pojavi $\mathrm{v}$ fragmentih religiozne legende, ki eseje žanrsko umeščajo $\mathrm{v}$ območje monumentalne spominske retorike. To je razvidno iz pripovedi o religioznem razlogu, ki govori proti migracijam vzhodnoevropskih Judov čez Atlantik: "Stara legenda o prihodu mesije natančno opisuje vstajenje mrtvih. Vsi Judje, pokopani v tuji zemlji, se bodo morali vrteti pod zemljo, dokler ne bodo dospeli v Palestino. [...] Bodo obujeni od mrtvih tudi mrtveci, potopljeni v vodo? Ali obstaja dežela pod vodo? [...] Judovskega trupla se ne sme secirati, $\mathrm{v}$ celoti in povsem nedotaknjen mora človek znova postati prah." (Roth, Juden 64) Oscilacije med empiričnim in monumentalnim načinom spominske retorike so opazne tudi na različnih ravneh pripovedi. Na ravni selekcijske strukture je očitno, da osebe in dogodki iz zunajbesedilne spominske kulture pripadajo tako komunikativnemu kot kulturnemu spominu - „Hohenzollerni (in z njimi nemški plemiški klub) so se priklonili hišnikom. Kaj lahko tu še pričakujejo Judje?» (82) Prehode med obema načinoma je nadalje moč zaslediti na ravni medbesedilnosti, meddiskurzivnosti in intermedialnosti. Kažejo se v številnih interferencah med različnimi diskurzi in jeziki ter njihovimi registri. Vsenavzoči jidiš kot osrednji vzhodnojudovski sociolekt, ${ }^{8}$ ki se pojavlja pri poimenovanju pripadnikov vzhodnoevropskega judovstva, njihovih specifičnih poklicev - med njimi "batlen", "humorist, norec, filozof, pripovedovalec zgodb « (35) - in v rimah - "Kim, kim, Jisruleki l aheim (domov) / v svojo drago domovino arain ...« (53) -, se prepleta $s$ citati iz judovske Biblije in vedno znova tudi s pregovori: "Judje so ovrgli pregovor, ki tu [v primeru antisemitizma v multietničnih in plurikulturnih pokrajinah habsburške Avstrije; M. B.] pravi, da ima tretji dobiček, kjer se dva prepirata. Judje so bili tretji, ki so vselej izgubili.« (17) Prehodi med monumentalnim in empiričnim načinom se prav tako kažejo $\mathrm{v}$ prepletu nanašanj na diskurze in medije kul-

\footnotetext{
${ }^{8}$ Imaginacijo jidiša lahko razumemo kot izraz avtorjeve fascinacije nad osrednjim judovskim idiomom, po drugi strani pa tudi kot dokaz Rothovega zanimanja za jidišizem.
} 
turnega spomina z referencami na medije komunikativnega spomina, konkretno na nemške časopise. Pripovedovalec jih z ironično uporabo specifičnih stalnih besednih zvez, kakršne so »organi javnosti« (15), "naslovni članek" (21) in »lokalno poročilo« (9), ${ }^{9}$ polemično kritično perspektivira. S prepletom jezikov obeh spominskih medijev pripovedovalec evocira diskurzivno večglasje, ki je instrument preizpraševanja taistih idejnih in kulturnih antagonizmov, ki jih, kot bomo videli $\mathrm{v}$ nadaljevanju, $\mathrm{z}$ razmejevanjem lastnega in drugega kulturnega reda sam vztrajno generira.

Osciliranje med izkustvenim in monumentalnim spominskoretoričnim načinom pride do izraza tudi na ravni pripovedovalčeve identitete in njegovega posredovanja. Bralec opazuje dogajanja z očmi prvoosebnega pripovedovalca, ki predstavlja osebni glas in komunikativni spomin. Prvoosebni pripovedovalec nastopa najprej v vlogi očividca, ki svoje doživljaje povezuje z opazovanji izkušnje drugega. Hkrati se pojavi avtodiegetski pripovedovalec, ki spregovori v imenu kolektiva in svojim izkušnjam pripisuje paradigmatični značaj, s čimer tudi on evocira izkustveni način. $\mathrm{Na}$ dogajalni ravni so nanizani pripovedovalčevi doživljaji. Ti se prvenstveno zrcalijo $\mathrm{v}$ njegovem notranjem svetu in se izražajo v številnih detajlih, ki pripadajo čutnim vtisom in čustvom ter se z doživljajsko pripovedjo vključujejo $\mathrm{v}$ komunikativni spomin. Pripovedno raven sestavljajo komentarji, analize, vrednotenja in osmišljanja pripovedovanega, $s$ čimer avtodiegetski pripovedovalec rekonstruira individualno-biografsko in kolektivno preteklost ter sočasnost in si ju na ta način prisvaja, kot je to razvidno iz pripovedi o obisku pri čudežnem rabiju (»Wunderrabbi«):

Naučil se je izreke besedil in božje zakone razlagati tako, da ne nasprotujejo zakonom življenja in da nikjer ne ostane vrzel, skozi katero bi se lahko izmuznil lažnivec. [...] Kdor je doživel toliko kot rabbi, je dvom že presegel. Stadij znanja je pustil za sabo. [...] Vzvišena znanost kirurga bolniku prinese smrt in prazna modrost fizika učencu zmoto. Človek ne verjame več tistemu, ki zna. Človek verjame verujočemu. (17)

Prvoosebna pripoved se prepleta s pripovedjo vsevednega pripovedovalca, ki pripovedovano umesti $\mathrm{v}$ oddaljeno obzorje preteklosti in prihodnosti vzhodnojudovske kulture in $s$ tem $\mathrm{v}$ območje kulturnega spomina. $S$ pozicije pripovedne avtoritete stopi $\mathrm{v}$ stik s fiktivnim bralcem, da bi ga omikal in poučil. Vsevedni pripovedovalec didaktično namero čustveno poudari, kar avtor pogosto grafično označi: "Zagotovo je bolje

\footnotetext{
${ }^{9}$ "Organe der Öffentlichkeit«, »Leitartikel«, »Lokalbericht«.
} 
sam biti nacija kot biti trpinčen od nacije. A vendarle je to zgolj boleča nujnost. Kakšen ponos za Juda, ki se je davno tega razorožil, še enkrat dokazati, da zna tudi eksercirati!« (19)

Še posebej očitni so prehodi med empiričnim in monumentalnim načinom $\mathrm{v}$ imaginiranih kronotopih, kar denimo velja za inscenacijo primarnega urbanega prostora, ki ga naseljujejo Judje: ta prostor "shtetl « v izvornih deželah in "ghetto " v deželah migracije - nastopa kot zgodovinski prostor razlikovanja in razmejevanja ter hkrati institucionalizirane religioznosti. Slednja vključuje atribute mitičnega spominskega prostora in nastopa kot sprožilec nihanja med obema spominskoretoričnima načinoma. Podobno velja za Palestino, ki je kot prostor $s$ številnimi sodobnozgodovinskimi kronotopičnimi obeležji z vidika sionistov umeščena $\mathrm{v}$ imaginarij komunikativnega spomina, medtem ko ji pri pravovernih Judih kot referenčnemu prostoru končnega zatočišča pripade osrednje mesto $\mathrm{v}$ oddaljenem obzorju kulturnega spomina: "Boji se [vzhodnoevropski Jud; M. B.] dezorientacije. Navajen je, da se trikrat na dan obrne proti 'mizrahu', proti vzhodu. To je več kot verski predpis. To je globoko občutena nujnost védenja, kje se nahaja. [...] Bolj ali manj ve, kje leži Palestina." (64) Prehodi med izkustvenim in monumentalnim načinom predstavljajo empirično obogatitev kulturnega spomina oz. njegovo umestitev v sedanjost, kar pride do izraza na številnih mestih, kjer pripovedovalec $\mathrm{z}$ doživeto sedanjostjo aktualizira kulturni spomin. Ta sicer tako izgubi nekaj svojega obvezujočega značaja, po drugi strani pa postane izkustvo, kodirano predvsem v vzhodnojudovskem polifoničnem spominu, integralni del kulturnega spomina, kot je npr. razvidno v pripovedi o nenavadnem artefaktu iz berlinskega geta:

Od časa do časa v Berlin prispe »Tempel Salomonis«. To svetišče je naredil neki gospod Frohmann iz Drohobiča v popolnem skladju s podrobnimi navedbami v bibliji, iz balzovca in papirmašeja in zlate barve. Nikakor ne iz cedrovine in pravega zlata kot véliki kralj Salomon. Frohmann trdi, da naj bi ta miniaturni tempelj gradil sedem let. Verjamem mu. [...] V tej okolici je vse improvizirano: tempelj [...], trgovina [...]. Še vedno je beg iz Egipta, ki se drži že stoletja. (50 sl.)

Empirični in monumentalni spominskoretorični način redno prehajata $\mathrm{v}$ antagonističnega, ki v esejih prevladuje. Prehodi v antagonistični način so najprej opazni na jezikovni oz. slogovni ravni, kar se kaže v posnemanju antisemitske idiomatike - Judje ne znajo piti [...]«(31), "oni uničujejo red" (37) itd. - in na ravni opisanega pripovedovalčevega posredovanja tam, kjer ta spregovori v prvi osebi množine in $\mathrm{z}$ gla- 
som skupnosti. Antagonistični način spominske retorike je vseprisoten v razmerjih med prostori in liki. Ta razmerja so zaradi številčnosti in raznolikosti za osvetlitev korelacije med spominsko retoriko in identitetnimi konstrukcijami še posebej zanimiva. Med semantiziranimi prostori izstopajo urbana okolja in prevladujejo kontrastna razmerja. Berlin in še posebno Dunaj nastopata kot identitetno ogrožujoča socio-kulturna prostora v diaspori: Dunaj zaradi politično vsiljenega stigmativnega razlikovanja in Berlin zaradi zapovedi preseganja takega razlikovanja, utemeljenega $\mathrm{v}$ kulturnem kozmopolitizmu, ki vodi $\mathrm{v}$ nepovratno asimilacijo: "Berlin izenači različne in ubije posebnosti. Zato v Berlinu ni velikega geta. [...] Najbolj judovska od vseh berlinskih ulic je žalostna Hirtenstraße." (49) Po drugi strani opažamo med insceniranimi urbanimi prostori razmerja, ki nasprotja presegajo. Pripovedovalec npr. kodira Pariz kot prostor organične asimilacije. Ta se prične na ravni jezika s prepletanjem kodov - Ta [g. Weingrod, judovski gostilničar v Parizu; M. B.] reče svoji ženi: ‘Daj mi glavno knjigo, s'il vous plaît.' In žena reče: 'Vzemite si jo z bifeja, si vous voulez!' Govorijo resnično veselo latovščino." (56) - in doseže svoj vrh v poistovetenju z ideologijo patriotizma, kar je npr. razvidno v pripovedi o priseljencu iz galicijskega Radziwillova. Amerika je v njej predstavljena kot prostor, kjer se vzhodnojudovski migranti v okoliščinah "talilnega lonca in multikulturalizma dokončno osvobodijo diktata zbirokratiziranega razlikovanja iz Evrope in se zaradi vseprisotnih črncev v socialni strukturi povzpnejo za stopnico višje, a so hkrati primorani $\mathrm{k}$ stalnemu pogajanju za identitetne elemente. Sovjetsko zvezo pripovedovalec opisuje kot prostor zapovedanega boljševističnega prevladovanja antisemitizma in diskriminatornega razlikovanja. Vsem trem integracijskim praksam, »organični« pariškega in ideološkima judovstva v Berlinu in Sovjetski zvezi, se vpisujejo utopične razsežnosti, skupaj z njimi pa tudi vizije "drugega stanja» (gl. Müller-Funk) in s tem alternativni vidiki historičnih družbenih praks v migracijskih deželah.

Podoben preplet kontrastnega in korespondenčnega ter s tem vpisovanja drugega oz. alternativnega je opaziti tudi v razmerjih med liki. Med njimi resda prevladujejo nasprotja, vendar pa pripovedovalec vzpostavlja tudi številna korespondenčna razmerja, še posebej očitno med liki iz različnih kulturnih redov. Mednje sodijo razmerja med judovskimi in nejudovskimi učenjaki - Obstajajo judovski učenjaki, ki od petih zjutraj do dvanajstih ponoči študirajo v molilnici, kot evropski učenjaki denimo v knjižnici.«(23) -, med vzhodnojudovskimi in nemškimi delavci, slovitimi kantorji in znamenitimi zahodnoevropskimi opernimi pevci (E. Caruso), vzhodnoevropskimi antisemiti in 
nemškonacionalnimi Judi, judovskimi in krščanskimi šahisti v dunajskih kavarnah itd. Pripovedovalec se z razkritimi korespondenčnimi razmerji med liki in skupnostmi ideološkokritično pozicionira do prevladujočih hegemonističnih družbenih diskurzov o vzhodnem judovstvu prav z zanj značilno perspektivo sočutja, nostalgije in ironije.

Pri narativizaciji ideološko kontaminirane komunikacije med lastno in tujo kulturo pripovedovalec spretno intrigira. $\mathrm{V}$ obravnavanih esejih je opaziti ambivalentnost $\mathrm{v}$ odnosu do obeh kultur. $\mathrm{Z}$ evrocentrične pozicije se diskurzivno istoveti z zahodno kulturo, hkrati pa je njegov odnos do nje izrazito kritičen. Zahodnjakom v komunikaciji z vzhodnoevropskim Judovstvom očita udomačeno animalnost, duhovno ozkost, civilizacijsko vzvišenost in moralno sprevrženost, ki "obide zakon z vljudnostnim klobukom v boječi roki« (11). Po drugi strani tudi kulturo vzhodnoevropskih Judov v odnosu do zahodne kulture modelira kot nasprotno, resonančno in dopolnilno tujost (gl. Schäffter). Tako judovskim družbenim praksam brez pomišljanja pripiše atribute nasprotne tujosti, še posebej takrat, kadar so te ideološko kodirane, kot je to razvidno iz predstavitve percepcije predstavnikov različnih judovskih skupnosti:

Prijatelju in sovražniku vsi vzhodni Judje predstavljajo zaprto fronto ali na videz zaprto fronto. Nič od vneme, s katero se posamezne skupine borijo druga proti drugi, od sovraštva in zagrenjenosti, $s$ katerima nastopajo pristaši enega čudežnega rabija proti pristašem drugega, in nič od zaničevanja, ki ga vsi verni Judje gojijo do sinov svojega naroda, ki so se na zunaj prilagodili šegam in noši svojega krščanskega okolja, ne prodre v zunanji svet. (24)

Hkrati pa vzhodnoevropsko judovstvo kot dopolnilna tujost naplavi na površje številne samoprevare zahodne kulture: $\mathrm{v}$ ogledalu socialnih in kulturnih praks vzhodnojudovskih migrantov prikaže patriotizem in človečnost kot samooklicana ideološka gradnika, kot manipulativen medijski konstrukt.

Primat v ideološkem privilegiranju identitete pripovedovalec vendarle najpogosteje pripiše zahodnim Evropejcem, kar mu omogoča, da je pri zavračanju ideoloških družbenih praks vzhodnih Judov lahko nedosleden in da ideološkost njihove identitete nadomesti z zgodovinsko izkušnjo. Tako judovski nacionalizem integrira $\mathrm{v}$ območje lastnega z ironičnim perspektiviranjem - "vsaka dežela, v kateri bivajo [...], zahteva od njih patriotizem in junaško smrt [...]. V tej situaciji je sionizem resnično edini izhod: če že patriotizem, potem bolje takšen za svojo deželo." (20) - in značilnosti sovjetskih Judov konstruira kot produkt zgodovinskega "zaničevanja, zatiranja in 
pogroma" (67). Ugotovitev o neobstoju berlinskega geta kaže, da pripovedovalec brezkompromisno zavrača asimilacijo v kulturni red dežele migracije in odgovornost zanjo pripisuje tako asimilatorjem kot asimilirancem. Podobno kot razkrita korespondenčna razmerja med liki je tudi zavrnitev asimilacije umeščena v ironično-nostalgično perspektivo, ki naj radikalizira kritično dekonstrukcijo zahodnoevropskih družbenih praks, vendar tudi razkrije samoprevare vzhodnojudovskega kulturnega reda:

Predali so se. [...] Njihova žalostna lepota je padla od njih in prašno siva plast nesmiselne žalosti in nizkih skrbi brez tragike je ostala na njihovih sključenih ramenih. [...] Sklepali so kompromise. Spremenili so svojo nošnjo, svoje brade, svoje lase, svojo božjo službo, svoj sabat, svoje gospodinjstvo - sami so še vztrajali v tradiciji, a se je izročilo odluščilo od njih. Postali so preprosti malomeščani. [...] Plačevali so davke, dobili prijavnico stalnega bivališča, vpisali so jih v register in izrekli so se za »nacionalnost«, za »državljanstvo«, ki sta jima bili po mnogih šikanah "podeljena«, uporabljali so tramvaj, dvigalo, vse blagoslove kulture. Imeli so celo »očetnjavo«. (16)

Brezkompromisno zavračanje asimilacijskih in kritika na račun ideoloških praks vzhodnoevropskega judovstva potekata z glasom avtoritativnega pripovedovalca vzporedno z neomajnim legitimiranjem vzhodnega judovstva. $\mathrm{Na}$ teh mestih antagonistični spominskoretorični način pogosto prehaja $\mathrm{v}$ monumentalnega. Prav preplet monumentalnega spominskoretoričnega načina z izkustvenim in antagonističnim, ki sicer prevladujeta, predstavlja ključno značilnost $\mathrm{v}$ pripovedni strategiji esejev. V nihanju med antagonističnim in monumentalnim spominskoretoričnim načinom se $\mathrm{v}$ dominantne družbene oz. kulturne diskurze vpisujejo številni drugi in nasprotni, tako da pripovedovalec $\mathrm{z}$ bralcem oblikuje alternativno spominsko skupnost in z njenim glasom tudi demonstrativno spregovori:

"Produktivnost « Judov ni nikoli očitno opazna. Če je dvajset generacij neproduktivnih tuhtačev živelo le za to, da proizvedejo enega samega Spinozo; če je potrebnih deset generacij rabinov in trgovcev, da se rodi en Mendelssohn; [...] vzamem to »neproduktivnost« v zakup. [...] Morda bi tudi Marx in Lassalle izostala, če bi iz njunih prednikov naredili kmete. (72)

Toda po drugi strani antagonistični način prehaja tudi v refleksivnega, na kar opozarja stopnjevanje literarne selektivnosti z izbiro mehanizmov, ki določajo konstrukcijo kolektivne kulture. V esejih se stopnjevanje selektivnosti kaže predvsem takrat, kadar kolektivni spomin določa problematika sedanjosti. Osrednji problem v očeh pripovedovalca 
predstavlja hegemonistični medialni diskurz o kulturi in spominjanju vzhodnoevropskih Judov. Osrednji vzvod refleksivnega načina v esejih je poleg reprezentiranja specifičnih kulturnih praks tudi nezanesljivi pripovedovalec. Ta pride do izraza $\mathrm{v}$ neskladjih in nasprotjih $\mathrm{v}$ pripovedih o identiteti likov in razmerjih med njimi. Neskladja so še posebej očitna, kadar so izvirno poetično kodirana, npr. pri imitiranju vzhodnojudovskega govora in njegove pripovedi. Primer za to je odlomek o omenjenem francoskem patriotu, sicer priseljencu iz Radziwillowa, ki se v diaspori v Parizu preživlja z mimikrijskim klovnstvom:

V Franciji sem govoril z nekim judovskim artistom iz Radziwillowa [...]. Izviral je iz družine glasbenikov. Njegov praded, njegov ded, njegov oče, njegovi bratje so bili judovski svatbeni muzikantje. On, edini, je lahko zapustil domovino in študiral na Zahodu. [...] »A kaj,« je rekel, »naj posvetni Jud dela resno muziko? Vedno sem klovn na tem svetu, tudi če o meni držijo resna predavanja [...]. Kaj bi slepil svet [...]? Naj se vrnem v Radziwillow in igram na judovskih svatbah? Ali ne bom tam še bolj smešen? [...] V Parizu Judje živijo prosto. Sem patriot, 'mam judovsko srce.« (57 sl.)

Paleto vzhodnojudovskih kulturnih praks na tem mestu kaže dopolniti s praksami, ki so vezane na specifične - pripovedovalec jih imenuje "nenavadne« - judovske poklice, med katere pripovedovalec, poleg že omenjenega batlena, uvršča še "prinašalce vode» (39) v izvorni deželi in "prodajalce kreditnih obrokov« (43) ter "prodajalce zraka» (46) oz. "z blagom iz zraka« (prav tam) v diaspori. Pripovedim o poklicnih praksah sledijo tiste o praksah sionističnih kolonov v Palestini, še posebej pa izstopajo pripovedi o ritualih pravovernih Judov ob verskih praznikih, porokah in pogrebih $\mathrm{v}$ izvorni domovini ali $\mathrm{v}$ diaspori. Njihova osrednja razlikovalna kulturna značilnost je preplet transcendentalnega in senzualnega, ki pride še posebej očitno do izraza $\mathrm{v}$ ritualih - med njimi posebno mesto zavzema shodnica -, umeščenih v prostore, ki jim pripovedovalec na stičǐšcu religije in umetnosti pripisuje hibridno simbolno identiteto:

V Parizu, kjer je nekaj bogatih vzhodnojudovskih skupnosti, predstavniki sinagog vsako leto za praznike povabijo enega od znamenitih pevcev in predmolilcev z vzhoda. Judje grejo nato k molitvi, kot gre človek na koncert, in tako njihova verska kot umetnostna potreba sta zadovoljeni. Možno je, da vsebina pétih molitev, prostor, v katerem jih izvajajo, stopnjujeta umetnostno vrednost pevca. (35)

Preplet duhovnega in religioznega s čutnim predstavlja eno od ključnih identitetnih značilnosti Rothove imaginacije sveta vzhodnoevropskega 
judovstva, prav tako pa tudi metaforo za drugo v odnosu do hegemonistične medializacije njihove kulture.

\section{Zaključek}

Raziskava je potrdila uporabnost modela spominske retorike kot dela kognitivne naratologije za sodobno naratološko analizo literarnih besedil, za osvetlitev družbenih in historičnih kontekstov ter etičnih vprašanj kot tudi za holistično interpretacijo kolektivne kulture. Rothovi Juden auf Wanderschaft po eni strani resda sodijo v kategorijo malih pripovedi, a ker reprezentirajo kolektivno preteklost in pripovedno legitimirajo značilnosti vrednostnega sistema vzhodnoevropskega judovstva, kar še posebej pride do izraza $\mathrm{v}$ monumentalni spominski retoriki, jih hkrati lahko uvrščamo tudi med velike pripovedi. Žanrsko so del klasične esejistike, saj jih zaznamuje tesna korelacija med pišočim jazom in delom samim, skepsa na račun pomena in vrednosti znanja, še posebej tistega institucionaliziranega, in vizija "drugega stanja» oz. utopična razsežnost pripovedovanega. S kombinacijo izkustvenega in antagonističnega spominskoretoričnega načina, ki nastopata $\mathrm{v}$ funkcionalnem sozvočju z monumentalnim in se mestoma dopolnjujeta še z refleksivnim, uspe versatilnemu pripovedovalcu legitimirati družbene prakse vzhodnoevropskega judovstva. Te postavlja v oddaljeno obzorje pozitivno zaznane in sprejete kolektivne kulture. $S$ kritično dekonstrukcijo zahodnoevropskih družbenih diskurzov, a zasidran na gibljivi točki med vzhodnojudovsko in zahodnoevropsko kolektivno kulturo, pripovedno in diskurzivno razkriva njune kulturne samoprevare in antagonizme ter $s$ prepletom antagonističnega $\mathrm{z}$ refleksivnim spominskoretoričnim načinom bralca ciljno senzibilizira za dojemanje konstrukcijskega značaja obeh kulturnih redov. Avtodiegetski in avtoritativni pripovedovalec legitimira vzhodnojudovsko kulturo predvsem s sredstvi izkustvene retorike in $\mathrm{z}$ antagonističnimi razmerji med skupnostnimi, njihovimi socialnimi in kulturnimi praksami in prostori, ki so prav tako vzvod kritične kulturne refleksije. Antagonizmi izvirajo iz kritičnega odnosa do zahodnoevropske kulture in njene ideološko izključujoče ter manipulativne medializacije vzhodnoevropskega judovstva, iz kritičnega odnosa do njegove ideološkosti in nenazadnje iz tudi iz doslednega zavračanja njegovih asimilacijskih praks. Prvoosebni pripovedovalec mestoma konstruira kulturno hibridno spominsko skupnost, ki temelji na človečnosti in jo prepleta $\mathrm{z}$ religiozno transcendenco. Humanost sicer privilegirano povezuje $\mathrm{z}$ vzhodnim judovstvom, a jo preko raz- 
kritih korespondenčnih razmerij med liki integrira tudi v individualne prakse nejudovskih likov. Refleksivni način pa s premikom spominskoretoričnega težišča $s$ kontrastnega na korespondenčnega in $\mathrm{v}$ kombinaciji s subverzivnostjo nezanesljivega pripovedovalca subtilno legitimira človečnost v njeni čezetnični razsežnosti ter jo v razmerju do naraščajočega barbarizma nazadnje izpostavi kot ultimativno vrednostno univerzalijo. Ta predstavlja ključno duhovno-idejno izhodišče za večjo odprtost do zaznavanja kulture vzhodnega judovstva v migracijskih deželah. Pripovedovalec vidi takšno zaznavanje kot realno alternativo ideološki zapovedi stigmativnega kulturnega razlikovanja in asimilacije. Kljub številnim kulturnim binarnostim, ki jih generira antagonistična spominska retorika, in historično pogojenemu pesimizmu o usodi Judov v Evropi - „Vernim Judom ostane nebeška tolažba. Drugim 'vae victis'.» (85) - ponujajo raznolike hibridne identitetne konstrukcije v Rothovih simbolnih popotovanjih bralcu številne signale za razkrivanje transdiferenc, če te pojmujemo kot pripadnost več kulturam in kot možnost idejnega večglasja $\mathrm{v}$ komunikaciji med Judi in drugimi religioznimi ter kulturnimi skupnostmi nekoč in danes.

\section{LITERATURA}

Baric, Daniel. »Joseph Roth et l'art du reportage à l'époque de la Nouvelle Objectivité«. Communications 71 (2001): 13-49.

Birk, Matjaž. »Vielleicht führen wir zwei verschiedene Sprachen ...«: Zum Briefwechsel zwischen Joseph Roth und Stefan Zweig. Münster: LIT Verlag, 1997.

Bos, Ronald. "Erdbeeren pflücken in Brody. Ein Besuch im Geburtsort Joseph Roths". Joseph Roth: Interpretation - Kritik - Rezeption: Akten des internationalen, interdisziplinären Symposions 1989, Akademie der Diözese Rottenburg-Stuttgart. Ur. Michael Kessler in Fritz Hackert. Tübingen: Stauffenburg Verlag, 1990. 47-63.

Erll, Astrid. Kollektives Gedächtnis und Erinnerungskulturen. Stuttgart/Weimar: Verlag J. B. Metzler, 2005.

Gelber, Mark. »'Juden auf Wanderschaft' und die Rhetorik der Ost-West-Debatte im Werk Joseph Roths«. Ur. Michael Kessler in Fritz Hackert. Joseph Roth: Interpretation - Kritik - Rezeption: Akten des internationalen, interdisziplinären Symposions 1989, Akademie der Diözese Rottenburg-Stuttgart. Ur. Michael Kessler in Fritz Hackert. Tübingen: Stauffenburg Verlag, 1990. 127-135.

Genette, Gérard. Seuils. Paris: Éditions du Seuil, 1987.

Juvan, Marko. »Esej kot zvrst transverzalnega diskurza«. Hibridni žanri: študije o križancih izkustva, mišljenja in literature. Ljubljana: Literatura, 2017. 107-130.

Koron, Alenka. Sodobne teorije pripovedi. Ljubljana: Založba ZRC, 2014.

Krevs Birk, Uršula. "Zu einigen Aspekten des Deutschen als Kontaktsprache des Slowenischen«. Linguistica 59 (2019): 155-173.

Kuzmany, Börries. Brody: Eine galizische Grenzstadt im langen 19. Jahrhundert. Wien: Böhlau, 2011. 
Müller-Funk, Wolfgang. Erfahrung und Experiment: Studien zur Theorie und Geschichte des Essayismus. Berlin: De Gruyter 1995.

Roth, Joseph. Briefe 1911-1939. Ur. Hermann Kesten. Köln/Berlin: Kiepenheuer \& Witsch, 1970.

Roth, Joseph. Juden auf Wanderschaft. Amsterdam: Allert de Lange/Köln: Kiepenheuer \& Witsch, 1985.

Roth, Joseph, in Stefan Zweig. "Jede Freundschaft mit mir ist verderblich«: Briefwechsel 1927-1938. Ur. Madeleine Rietra in Rainer Joachim Siegel. Göttingen: Wallstein Verlag, 2011.

Schäffter, Ortfried. "Modi des Fremderlebens«. Ur. Ortfried Schäffter. Das Fremde: Erfahrungsmöglichkeiten zwischen Faszination und Bedrohung. Opladen: Westdeutscher Verlag 1991. 11-24.

Sternburg von, Wilhelm. Joseph Roth: Eine Biographie. Köln: Kiepenheuer \& Witsch, 2010.

\section{The Rhetoric of Memory in the Literary Essayism of Joseph Roth}

Keywords: Austrian literature / Roth, Joseph: The Wandering Jews / literary essayism / Eastern Europe / Jewry / Judaism / collective memory / collective identity / ideational and cultural polyphony

The present discussion focuses on Juden auf Wanderschaft (1927), the central literary-essayistic work with a Jewish theme by the Jewish-Austrian writer and journalist Joseph Roth (1894-1939). Based on the theory of rhetoric of memory (A. Erll), it sheds light on narrative strategies and the correlation between the narrativization of collective memory and the literary representation of identities and cultural practices of Eastern European Jewry. Anchored in the flexible point between Western European and Eastern Jewish cultures, the author legitimizes cultural practices of Eastern European Jewry embeded between the spiritual and the sensory by connecting, in functional harmony with the monumental, the antagonistic and the experiential modes of the rhetoric of memory. In the prism of critical deconstruction of Western European ideological discourses, the discussion simultaneously reveals Jewish cultural self-deceptions, and, interweaving the antagonistic and the reflexive modes, sensitizes the reader for the perception of "the other status" and for the constructional character of culture. The shift of the barycenter of the rhetoric of memory from the contrastive to that of correspondence models humanity in the trans-ethnic dimension, and exposes it as an ideational postulate for the attitude towards Eastern Jewry as a complementary foreignness (O. Schäffter). 
Despite cultural binarities as a product of antagonistic rhetoric of memory and irrespective of the historical pessimism relating to the fate of Jews, hybrid identity constructions offer the reader convincing signals for disclosing transdifferences and possibilities of ideational polyphony in intercultural communication.

1.01 Izvirni znanstveni članek / Original scientific article UDK 821.112.2.09(436)Roth J.

DOI: https://doi.org/10.3986/pkn.v43.i1.07 